\title{
Holocene fire activity and vegetation response in South Eastern Iberia
}

\author{
Graciela Gil-Romera ${ }^{1,2 *}$, José S. Carrión ${ }^{3}$, Juli G. Pausas ${ }^{4}$, Miguel Sevilla-Callejo, ${ }^{2,5}$, Henry F. \\ Lamb $^{2}$, Santiago Fernández ${ }^{3}$, Francesc Burjachs ${ }^{6}$. \\ 1. African Studies Centre. University of Oxford, 92 Woodstock Road, Oxford OX2 7ND. United Kingdom \\ 2. Institute of Geography and Earth Sciences. University of Wales. Aberystwyth, SY23 3DB, United Kingdom \\ 3. Department of of Plant Sciences, Faculty of Biology, Universidad de Murcia, Campus de Espinardo, 30100. \\ Murcia, Spain \\ 4. Centro de Investigaciones sobre Desertificación CIDE, CSIC, Apartado Oficial, 46470 Albal, Valencia, Spain \\ 5. Dept. Geography. C/ Francisco Tomás y Valiente, 1 Universidad Autónoma de Madrid Madrid E-28049, Spain \\ 6. Catalan Institution for Research and Advanced Studies ICREA, Passeig Lluís Companys 23, 08010 Barcelona, \\ Spain \\ * Contact email: gil.romera@gmail.com
}

\begin{abstract}
Since fire has been recognised as an essential disturbance in Mediterranean landscapes, the study of long-term fire ecology has developed rapidly. We have reconstructed a sequence of vegetation dynamics and fire changes across south-eastern Iberia by coupling records of climate, fire, vegetation and human activities. We calculated fire activity anomalies (FAAs) in relation to $3 \mathrm{kyr}$ cal BP for 10-8 kyr cal BP, $6 \mathrm{kyr}$ cal BP, $4 \mathrm{kyr}$ cal BP and the present. For most of the Early to the Mid-Holocene uneven, but low fire events were the main vegetation driver at high altitudes where broadleaved and coniferous trees presented a highly dynamic post-fire response. At mid-altitudes in the mainland Segura Mountains, fire activity remained relatively stable, at similar levels to recent times. We hypothesize that coastal areas, both mountains and lowlands, were more fire-prone landscapes as biomass was more likely to have accumulated than in the inland regions, triggering regular fire events. The wet and warm phase towards the Mid-Holocene (between ca. 8 and $6 \mathrm{kyr}$ cal BP) affected the whole region and promoted the spread of mesophytic forest co-existing with Pinus, as FAAs appear strongly negative at $6 \mathrm{kyr}$ cal BP, with a less important role of fire. Mid and Late Holocene landscapes were shaped by an increasing aridity trend and the rise of human occupation, especially in the coastal mountains where forest disappeared from ca. $2 \mathrm{kyr}$ cal BP. Mediterranean-type vegetation (evergreen oaks and Pinus pinaster-halepensis types) showed the fastest post-fire vegetation dynamics over time.
\end{abstract}

Key words: palaeoecology, charcoal, fire history, post-fire response, Mid-Holocene, Mediterranean Basin. 
Gil-Romera et al. - 2

\section{Introduction}

There is increasing evidence of the role of fire in explaining the history of the natural landscapes of the Mediterranean (Pausas and Keeley, 2009). Fire is a well known disturbance in Mediterranean ecosystems, and significant progress in fire ecology of these ecosystems has been achieved during recent decades (e.g. Bond and Midgley, 2001; Bradstock et al., 2002; Keeley, 1991; Pausas et al., 2004). Fire is now considered an inherent element of many ecosystems, including those of the Mediterranean (e.g. Ojeda et al., 2005; Pausas et al., 2008); however changes in fire activity may greatly impact the sustainability of some ecosystems (Elmqvist et al., 2003; Lavorel et al., 1998; Moritz and Stephens, 2008). Hence the understanding of long-term relationships between vegetation, climate change and fluctuations in fire and human activity in the Mediterranean basin may help to assess the ecosystem's resilience to changing fire activities and human impact. Since conventional ecology is often limited when addressing issues within time frames beyond instrumental records, palaeoecological methods may serve as an adequate alternative, as proven by the abundant literature that has been produced across the European Mediterranean region (Colombaroli et al., 2007; Colombaroli et al., 2008; Sadori and Giardini, 2007; Tinner et al., 2009; Vannière et al., 2008). This is especially relevant under the current scenario of increasing temperatures in Southern Europe (Pausas, 2004), where fire management may be critical in the near future for biodiversity and landscape management.

The southern European peninsulas are characterised by a long history of human occupation which has also determined the vegetation structure and its response to rapid environmental fluctuations. In this sense the Iberian Peninsula is no different, and its southern sector has been shaped by cultural transitions, from metallurgic to agro-pastoral societies that have occupied the area at various times and places.

This study is focused on understanding Holocene vegetation history and the local fire activity of southeastern Spain (Fig. 1). Specifically, we aim 1) to explore the change in fire activity and vegetation throughout the Holocene in SE Iberia; and 2) to infer the role of climate and human activity as drivers for vegetation change. To answer these questions we combined the results from six pollen and charcoal records from an altitudinal gradient in order to analyze the long-term postfire vegetation response to different degrees of human occupation and topographical complexity.

\section{Study area}

The six sites studied are situated along an environmental gradient from 225 to 1900 masl (Fig. 1, Table 1) in south-eastern Iberia. This region includes several of the most arid territories of Europe (Puigdefábregas and Mendizábal, 1998) although the topographical complexity makes rainfall and temperature vary considerably from the highest Baetic Mountains to the Tabernas Desert. The region is a hotspot of plant diversity (Médail and Quézel, 1999) lying on the Baetic-Rifan complex, and subject to increasing human pressure due to growing population density and all the direct and indirect impacts associated with it (Blondel and Aronson, 1999). 


\subsection{Vegetation patterns}

The current vegetation of the study area is dominated by Mediterranean shrublands with some patches of forest. High-elevation areas above $1400 \mathrm{~m}$ are dominated by scrublands of Berberis hispanica and Juniperus oxycedrus, with Crataegus monogyna, Quercus rotundifolia, Lonicera arborea, Prunus ramburii and a ground cover of hard-leaved grasses; Pinus nigra and P. sylvestris are the conifers representative of the uppermost forest belts. Prostrate thorns, such as Vella spinosa, Hormatophylla spinosa, Erinacea anthyllis, or Echinospartum boissieri, become the dominant vegetation in the wind-exposed areas above $1800-1900 \mathrm{~m}$. The area between 800 and $1400 \mathrm{~m}$ is dominated by evergreen holm oaks while the deciduous oak forests are restricted to the most humid sites on deep soils. These prevail in the west and northwest slopes in Siles, dominated by Quercus faginea, occasionally accompanied by Acer granatense and rarely Taxus baccata, with relict Corylus avellana forests developed in shady valleys. The zone between $200-800 \mathrm{~m}$ is characterized by rich communities of Pistacia lentiscus, Quercus coccifera, Chamaerops humilis, Ephedra fragilis, Olea europaea, and a diversity of thorny Fabaceae. Xero-sclerophyllous brushwood characterized by Ibero-North African species as Maytenus europaeus, Ziziphus lotus, Periploca angustifolia, Withania frutescens and perennial chenopods, are abundant along the southern and eastern slopes below $400 \mathrm{~m}$.

\subsection{Archaeological settings}

Archaeological sites in the region are very diverse, both continuity and age wise. However, human occupation has been apparent since early Neolithic times and particularly intense at some of the sites (Table 2). The settlement pattern has been featured by phases of intense occupation alternating with episodes of abandonment, and it is likely that the early human communities were unevenly distributed across SE Iberia (Carrión et al., 2007).

Human occupation was earlier in the mountain areas of Baza and Gádor than at lower elevetaions at Siles and Villaverde (Sánchez-Quirante, 1998). At Siles, pastoralism and deforestation are recorded since 7.5 kyr cal BP (Barandiarán, 2002; Castro et al., 1999) while Villaverde, by contrast, was not occupied probably because these inland sites have a rough topography with arduous access conditions, include fairly unproductive soils and harsh, continental climates. An the other extreme is Navarrés, where its temperate setting, fertile land and sheltered situation at the bottom of a valley have supported human settlements since the Upper Palaeolithic and early Neolithic (Díaz-Andreu and Keay, 1997; Martí, 1988; Martí et al., 1980), with yet stronger human pressure since 4 kyr BP (Butzer, 2005; McClure et al., 2008). Well documented archaeological settlements alaso appear at Baza and Gádor (Sánchez-Quirante, 1998). The occupation of these areas expanded in the Bronze Age (Chalcolithic and Argaric periods in the regional terminology) and Roman period (Díaz-Andreu and Keay, 1997; Rodríguez-Ariza and Moya, 2005).

In the inland mountains (Cañada, Siles and Villaverde) archaeological evidence is not as clear, and anthropogenic activity is difficult to trace prior to the Roman occupation (ca. $2000 \mathrm{yr}$ BP) (DíazAndreu and Keay, 1997; Rodríguez-Ariza and Moya, 2005). Livestock grazing may have been present for longer, since these are montane areas suitable for summer pastures and livestock was already present in the peripheral lowlands (Martí, 1988).

The increasing human impact before and from the Roman period has been extensively documented (Cámalich and Martín, 1999; Rodríguez-Ariza and Moya, 2005; Rodríguez-Ariza and RuizSánchez, 1993). Social and economic development increased with demographic pressure. This population pressure would have caused a considerable environmental transformation in order to 
satisfy the agricultural, and trade demands of the Roman Republic (Blázquez Martínez, 1974). Similarly, the Roman occupation brought the expansion of species with economic value such as Olea (Rodríguez-Ariza and Moya, 2005).

\subsection{Current fire activity}

Fire frequency in peninsular Spain for the period 1974-2000 has been analyzed by Vázquez et al. (2006) in $10 \times 10 \mathrm{~km}$ grid units. While the national average is ca.56 fire events per grid, Vázquez et al. (2006) report between 5 and 25 fires over the 26 years in most of the six study site grids, except for Navarrés where the number of fires is between 25 and 100. The relatively high fire activity in Navarrés is probably related to human activities since this site shows a higher population density; this fact, together with important landscape changes, increases the probability of starting and spreading fires (Pausas, 2004).

\section{Materials and methods}

\subsection{Pollen, charcoal and dating}

The Holocene vegetation and fire records are derived from lacustrine and peaty sediments (Carrión, 2002; Carrión et al., 2001a; Carrión et al., 2007; Carrión et al., 2001a; Carrión et al., 2001b; Carrión et al., 2003a; Carrión and Van Geel, 1999) (Table 1) where fossil pollen, micro- and macrocharcoal have been analyzed. When possible, two types of Pinus pollen were distinguished; pinasterhalepensis type and sylvestris-nigra type. For the purposes of this paper, the palynomorphs found have been grouped under different functional types based on life form, leaf type and post-fire regeneration strategy (Table 3). Microscopic charcoal particles in pollen slides were counted following the method proposed by Tinner and $\mathrm{Hu}$ (2003) and Finsinger and Tinner (2005). Charcoal concentration particles $\left(\mathrm{cm}^{-3}\right)$ were estimated with the same method as for pollen; charcoal area $\left(\mathrm{mm}^{2} \mathrm{~cm}^{-3}\right)$ was calculated following Tinner and $\mathrm{Hu}$ (2003). Charcoal accumulation rate (CHAR, $\mathrm{mm}^{2} \mathrm{~cm}^{-2} \mathrm{yr}^{-1}$ ) was used in order to have a time-fitted value of charcoal. Contiguous core sampling would provide the temporal resolution necessary to detect individual fire events and therefore would help reconstructing local fire regimes. Since our charcoal record is based on pollen-slide counting, in widely spaced core samples, we cannot accurately reconstruct fire frequencies. However changes in charcoal abundance provide valuable information for comparisons of fire activity between periods (Whitlock et al., 2006).

Chronologies are based on radiocarbon-dated bulk sediment from every core following conventional and AMS methods. Dates were calibrated using the curve INTCAL98 included in CALIB 4.3 (Stuiver et al., 1998) (Table1). Age-depth models were based on linear interpolation between adjacent pairs of dates. Pollen diagrams were produced using the software Tilia and TiliaGraph (Grimm, 1991) and edited with Corel Draw X3C.

\subsection{Fire activity anomalies (FAAs)}

In order to understand the fire dynamics at critical phases of climate change or human occupation we calculated the fire activity anomalies (FAAs) of target periods versus $3 \mathrm{kyr}$ cal BP, when more intensive human activities are reported across the area (Martí, 1988). Therefore the anomalies correspond to the difference in CHAR at particular times in comparison with the $3 \mathrm{kyr}$ cal BP 
values. A similar approach was used by Whitlock et al (2007) to determine the climatic controls of Holocene fire patterns in South America in reference to the European arrival.

Prior to anomalies estimation, CHAR series were normalized following Carcaillet et al. (2002). As explained by these authors, CHAR normalization allows series to be assessed using a comparable scale for all the sequences (Fig 2a and c), reducing the variability due to sedimentation rate, vegetation type or catchment physiography. Normalized charcoal series (NCHAR) were averaged per millennium, so each data point to calculate FAA is centred on a millennium, e.g. $6 \mathrm{ka}$ corresponds to time elapsed between 6500 and 5500 calibrated years before present. When data were available, NCHAR was averaged for the present which corresponds to the last 500 years (Carcaillet et al., 2002).

We have characterised FAAs for four different periods as positive, negative, strongly negative or without change in comparison to the fire activity during 3-2 kyr BP.The NCHAR values used for the FAA estimation correspond to the Early Holocene, defined as 10-8 kyr BP - because some of the chronologies record less than $10 \mathrm{kyr}$ (Baza and Gádor); Mid-Holocene, corresponding to $6 \mathrm{Kyr}$ cal BP; Late Holocene, which corresponds to $4 \mathrm{kyr}$ cal BP and the Present which is referred to the last 500 years.

\section{Results}

\subsection{Holocene fire activity in south-eastern Iberia}

Fire activity, deduced from NCHAR sequences (Figs 2, 3a and 3b), show a general stability during the early Holocene, with decreasing values towards the early- mid holocene transition and a widespread increase since ca. $3 \mathrm{kyr}$ cal BP. In spite of this general regional trend in fire activity, abrupt fire fluctuations and inter-site variability should not be overlooked. The coastal mountains sites, and the lowland site of Navarrés show unstable NCHAR values since the early Holocene. In particular Baza and Gádor were subject to rapidly fluctuating fire activity for most of the first half of the Holocene, finally increasing since 3-2 kyr cal BP. The more continental locations at middle altitudes show minor changes in fire activity for much of the Holocene, especially in the case of Cañada and Villaverde, while fire activity at Siles oscillates faster. The FAAs compared to $3 \mathrm{Kyr}$ cal BP suggest a general concurrence of negative anomalies at 10-8 kyr cal BP that becomes strongly negative during $6 \mathrm{Kyr}$ BP to reach a stable negative value at $4 \mathrm{Kyr}$ BP (Fig. 4). Interestingly, positive FAAs are almost absent for most of the Holocene but in the case of Navarrés and for other inland sites during the last two millennium, confirming the overall regional increase of fire activity for the last three thousand years.

\subsection{Regional vegetation change inferred from fossil pollen}

Despite different chronologies and time resolution over the sequences, it is possible to describe a general pattern of vegetation change comprising four main phases (Figs. 3a and 3b):

1. Early Holocene (10 to $7.5 \mathrm{kyr}$ cal BP): during this period of Pinus forests dominate at most of the sites. All the localities show plant assemblages where the mesic component is scarce while Pinus is abundant; especially Pinus nigra-sylvestris. The woodlands represent a legacy of the lateglacial developments where Pinus has a key role in the woodlands while preserving a poor understory (Carrión et al., 2001a).

2. Middle Holocene (7.5-6 to $4.5 \mathrm{kyr}$ cal BP). A regional increase in mesophytes and deciduous Quercus is remarkable. Pines progressively decline although not synchronously at all of the sites. Microfossils indicative of relatively high lake levels (e.g. Botryococcus) prevail during 
this period (Carrión, 2002). Different trends in lake-level occurred, with these indicators decreasing in Gádor and increasing in Navarrés through time.

3. Mid-late Holocene transition ( 4.5 to $2 \mathrm{kyr}$ cal BP). The landscape in eastern Iberia shows an important reduction in tree cover and a greater role of the herbaceous layer dominated by xerophytes and Poaceae. The remaining woody elements include Mediterranean scrub and evergreen Quercus and a fluctuating occurrence of Pinus and deciduous oaks.

4. Late Holocene ( $2 \mathrm{kyr} \mathrm{BP}$ to the present): There is a general opening of the landscape where the grasses, thorny scrub, and xerophyte component become dominant. A prominent increase in the anthropogenic pollen indicators is identified in Siles, concurrent with Pinus reexpansion in most of the records except at Baza.

\section{Discussion}

The existence of long-term fire activity patterns in the Mediterranean Basin has been proved in different local and regional approaches (Wick et al., 2003; Sadori and Giardini, 2007; Colombaroli et al., 2007; Sadori et al., 2008; Turner et al., 2008; Tinner et al., 2009; Vannière et al., 2008). These approaches show in some cases synchronous trends but also many unexpected ecosystem responses due to particular physical settings, microclimatic aspects and different models of human agency. Southeastern Iberian forest dynamics agree with this sub-continental framework and, as illustrated in this paper, fire activity has fluctuated temporally but also spatially throughout the Holocene (Figs $3 \mathrm{a}, 3 \mathrm{~b}$ and 4). This finding is in agreement with current fire activity in Mediterranean ecosystems, which has been demonstrated to be very erratic in time and space depending on land use, population density, biomass fragmentation and fuel availability (Pausas, 2004; Vannière et al., 2008).

\subsection{Fire activity anomalies and vegetation response: the role of fire in south-eastern Iberia}

Relatively colder conditions than those of today would have prevailed in the region during the onset of the Holocene. The decreasing difference between January and July insolation at $37^{\circ} \mathrm{N}$ would have produced a lessening of temperature seasonality during the Early Holocene, with warmer winters and cooler summers. Under this early holocene climate, cooler than today's, but not necessarily drier, pine woodlands developed under postglacial conditions were still successful. Some of these wooded areas in the mountains were probably Scots or European black pine forest supported by the low fire activity - negative FAA across the region. These pines lack any particular post-fire strategy (Table 3) (Pausas et al., 2008; Tapias et al., 2001) and therefore they are less successful than the Aleppo and Maritime pines (with serotinous cones) under intense canopy fire regimes. Thus during this period fires would have been limited to the understory level.

The Holocene temperature rise in the Mediterranean Basin has been widely discussed across different regions (Cheddadi et al., 1996; Prentice and Webb, 1998; Sadori et al., 2008; Tinner, et al., 2009) as well as in the Iberian Peninsula (García Antón et al., 1995, 1997; Franco Múgica et al., 1998, 2001; Carrión et al., 2001a, 2001b; Benito Garzón et al., 2007; Gil García et al., 2007; Morellón et al., 2008). These studies report a more benign climate with a shorter drought season between ca. 8.5 and 5.5. kyr cal BP. Broadly speaking a tendency towards warmer and wetter climate is found in all the records considered in the present analysis where broadleaved trees - both evergreen and deciduous - replaced conifers in most sites. Some of these areas would have acted as glacial refugia, enclosing some marginal oak forests that would have remained over the glacial and postglacial period (Brewer et al., 2002; Carrión et al., 2003b; Petit et al., 2002). Broadleaved elements were continuously present at the coastal mountain areas since the beginning of the 
Holocene, while in the intramontane regions and the lowlands the spreading of deciduous forest began abruptly at ca. $8 \mathrm{kyr}$ cal BP as a consequence of the favourable climatic conditions. Thus deciduous Quercus and mesophytes reached their maximum expansion between 7.5 and 6 kyr cal BP, when the lowest fire activity (low levels of both CHAR and FAA) is registered, except at Navarrés where the mid-Holocene presented positive FAAs (Figures 2, 3a, 3b and 4). If fire activity is reduced, mesophytes become superior competitors to Aleppo and Maritime pines, which are shade intolerant and obligate seeders (i.e., they germinate readily after fire and increase their population size in the open spaces generated by the fire). On the whole, a likely mid-holocene scenario in the SE Iberian Peninsula would imply the initial expansion of mesophytes and evergreen Quercus owing to warmer and wetter conditions as fire activity decreased due to shorter dry seasons produced by a less marked seasonal insolation. These results are coherent with the mid-holocene vegetation response found at similar latitudes in Southern Europe (Sadori and Giardiani, 2007; Tinner et al., 2009), where decreasing fire activity aided by growing moisture availability permitted the expansion of broadleaved forests (Vannière et al., 2008).

Interestingly all sites, but Navarrés, show similarly negative FAA at 4 kyr cal BP, indicating an increment in fire activity compare to the previous Mid-Holocene phase, but still not as high as the fire activity after $3 \mathrm{Kyr}$ cal BP (Fig 4). Arid events over the second half of the Holocene in the Mediterranean Basin have been extensively recognized, although happening at different intervals in different regions (Tinner et al., 2009). After the benign climate during the mid-Holocene, arid conditions were probably strengthened in south-eastern Iberia through recurrent drought spells (Carrión, et al., 2007). Fire activity steadily intensified since ca. 6 kyr cal BP, being particularly strong from ca. 4 kyr BP onwards (Vannière et al., 2008), promoting the regional spread of Mediterranean and xerophytic taxa.

Increasing aridity and fire activity would have triggered fast threshold responses in the Quercus and Pinus forests (Carrión et al., 2002), with fast but resilient changes between 5 and 2 kyr cal BP, as happened in the mountains of Gádor. Simultaneously, the changing fire pattern between 6 and 4 kyr cal BP probably facilitated the succession from the southern Iberian mesophytic woodlands into a more Mediterranean scrub composition. This reaction would not be exclusively dependent on the post-fire strategy as deciduous and evergreen Quercus, as well as many other Mediterranean taxa, are resprouters (Table 3), responding effectively to fire. However, only the schlerophylls would have been able to spread faster than mesophytes within the increasingly arid conditions. A likely regional landscape during the mid-late holocene transition would be one where, under higher fire activity than the Mid-Holocene and increasing aridity, the evergreen component thrived better.

During the Late Holocene, from ca. 3 kyr cal BP onwards, forests became relatively unstable and very responsive to the strong fire dynamics. Fire activity, although not necessarily stronger in terms of intensity and frequency - since these are parameters difficult to assess from pollen-slide charcoal counts -, turned into abrupt episodes, as those at Siles or Gádor. Thus oak forest and mountain pines contracted and xerophytes expanded as fire activity became more dynamic in all sites recorded. The last millennium shows positive FAA in Siles and Cañada and still negative in Baza, where the maximum fire activity occurred at 3-2 kyr cal BP.

\subsection{Fire pattern in the context of climate and human driven changes.}

Differences in the fire signal recorded in the six sites suggest that fires are sensitive to the environmental gradient separating more continental mid-altitude sites from high altitude coastal ranges. This is noticeable in the mountain areas of Baza and Gádor where FAAs are relatively 
negative in all the time slices selected. At the inland sites, Villaverde, Siles and Cañada, CHAR values fluctuated synchronously, from levels similar to those reached at the Roman Period -ca. 2 cal Kyr BP- to strongly negative, with a later rise. This pattern could be due to differences in the vegetation composition and to variable climatic constraints, but also to a heterogeneous pattern of human occupation. Thus while the inner part of the Segura mountains, Siles and Villaverde, have been much less inhabited (Burjachs, 1997; Carrión, 2002; Jordán, 1992) with a late human impact on vegetation, the southern mountains of Baza and Gádor have a long history of human occupation (Buxó, 1997; Carrión, et al., 2007; Carrión, et al., 2003; Sánchez-Quirante, 1998) as in the coastal area of Navarrés (Fig 1 and Table 2).

Coastal mountains remained more humid than the continental sites under the early holocene climatic conditions. These areas experience a faster forest expansion due to the Mediterranean influence while fire activity kept highly fluctuating levels. These fires were most likely climatically induced, although early grazing pressure cannot be rejected as the practice of burning to form new pastures has been recognized in these mountains during the Neolithic. Increasing human pressure over the Holocene would have changed fire controls from climatic to more human related. Thus mining activities have been very prevalent in the southern mountains being one of the oldest areas of Europe presenting metallurgy as a common practice. Chalcolithic settlements in this region occur between ca 5-4.9 and 4.4-4.2 kyr cal BP (Castro, et al., 1999; Nocete, 2001) (Fig 4) and these would have implied an increasing need of wood resources. As late holocene aridity and human pressure continued towards Roman times, vegetation composition changed at high altitudes, leading to a Pinus-Quercus forest. These forests would have been resilient to fire between 6 and 2 kyr BP to eventually recede in favour of more xerophytic elements and giving way to open landscapes. These would have represented a positive feedback to the increasing fire activity, so both human and climatic induced changes accelerated the fire dynamics from the mid Holocene. A different scenario appears in the more continental mid-altitude sites of the Segura range. Vegetation seems less responsive to fire activity, as this remained at relatively stable levels over time (Fig 3a and 3b). Only in Siles was fire activity rather dynamic conditioning the Pinus forest response, with a strong positive feedback to fire activity as these are obligate seeding Mediterranean-type pines. Human pressure in these areas, although present, has always been less important than in the coastal sector; fewer settlements have been found and most of them are from Roman-Medieval times. There is some evidence of grazing and hunter-gathering populations during the Neolithic but it is not clear the extent of agriculture in this area at that time (Buxó, 1997).

Navarrés constitutes a counterintuitive case of this regional model. This is the only site presenting a positive FAA during the Mid-Holocene while the spread of Quercus was delayed compared to other sites. It is worth considering that the same warm and wet mid- holocene phase provoked a different fire response in Navarrés. Increasing winter rainfall during the Mid-Holocene would have provoked the spread of a fire prone biomass in the coastal lowlands and therefore more likely fire events as the precipitation- evapotranspiration ratio remained the same (Turner et al., 2008). Additionally, human activity could explain the increasing fire activity from 5-4 Kyr cal BP as these easily accessible valleys of Navarrés have been heavily populated since the Neolithic (Badal, 1988). Different phases of agriculture intensification have been recognized in these settlements from as early as 7 kyr cal BP (Martí, 1988), as well as slash and burn in pine woodlands, although these are not easily recognizable in our record. These mid-Holocene fires would have promoted the forest change from Scots and European Black pine to oak and Aleppo pine, while a positive selection of oaks by humans could be possible owing to the fodder value of acorns for livestock. These hypothesis are not mutually exclusive and probably human agency, the mid 
holocene biomass growth as well as the aridity trend imposed from the Mid to Late Holocene, would explain the positive FAA in Navarrés from ca $6 \mathrm{kyr}$ cal BP.

A plausible hypothesis explaining the differences in fire activity across the whole south eastern region is that reduced moisture availability in the Segura range always conditioned slow forest development and biomass accumulation so open landscapes were more common than at higher altitudes, preventing fast and abrupt fire events. As human occupation increased at high altitudes, anthropogenic pressure became a superimposed factor influencing vegetation and accelerating fire dynamics with the subsequent vegetation response until the final forest collapse two thousand years ago. Since human impact was relatively scarce in the Segura area until relatively recent times, vegetation and fire dynamics would have always been primarily controlled by climate fluctuations and scarce fuel accumulation. The coastal lowlands were subject of increasing rainfall patterns during the Mid-Holocene promoting the biomass expansion and therefore a higher fire activity.

\section{Conclusions}

Through the combined analyses of fire activity and Holocene vegetation history from six localities in south-eastern Iberia we have improved our understanding of the long-term post-fire vegetation response and the fire-climate-vegetation relationship.

We have shown how Mediterranean forests in south-eastern Iberia experienced increasing fire activity phases for much of the Holocene up to the the last $3 \mathrm{Kyr}$ cal BP, from relatively negative fire activity anomalies during the early Holocene becoming strongly negative during the midHolocene to reach its maximum ca. $3 \mathrm{cal} \mathrm{Ktr}$ BP. The different post-fire responses of the vegetation types partially explain the long term vegetation dynamics. Accordingly mountain pines were probably worse competitors than oaks and Mediterranean scrub taxa under increasing fire activities, while Mediterranean pines (Pinus pinaster-halepensis) were more resilient to fire changes.

Despite regional discrepancies due to different environmental features, the coastal highlands have always been more populated than the inland ones presenting earlier and more abrupt fire activities. The coastal lowland vegetation responded positively to the mid-holocene increasing rainfall, spreading a mesophilous biomass and therefore the fire activity. The presence of human activity since the Neolithic would have enhanced the effects of the mid-late holocene arid pulses, increasing fire activity. In the Segura mountains climate conditions have controlled fire and vegetation dynamics for much of the Holocene, where only at ca. $2 \mathrm{kyr}$ cal BP has anthropogenic action become evident. Overall, this study shows that long-term fire records are essential to address questions linked to forest resilience and threshold responses in Mediterranean landscapes, and are relevant to conservation and landscape management strategy.

Acknowledgements: This paper has been funded by the projects CGL2006-2956-BOS, GRACCIE CONSOLIDER INGENIO 2010 Ministerio de Ciencia e Innovación of Spain, and PaleoDiversitas Fundación Séneca, Murcia. We are thanked to Drs. Mitchell Powell and Philip Higuera, who made relevant suggestions for the quantitative analyses and to Dr. Thomas Gillespie for reviewing an early draft of this manuscript. 
Gil-Romera et al. - 10

\section{References}

Badal, E., 1988. Resultados metodológicos del estudio antracológico de la Cova de les Cendres (Alicante, España). 57-70.

Barandiarán, I.M., B.; del Rincón, M.A.; Maya, J.L., 2002. Prehistoría de la Península Ibérica. Ariel-Prehistoria, Barcelona.

Benito Garzon, M., Sanchez de Dios, R. and Sainz Ollero, H., 2007. Predictive modelling of tree species distributions on the Iberian Peninsula during the Last Glacial Maximum and MidHolocene. Ecography 30, 120-134.

Blázquez Martínez, J.M., 1974. Economía de Hispania durante la República romana. Revista Internacional de Sociología 32, 19-57.

Blondel, J. and Aronson, J., 1999. Biology and Wildlife in the Mediterranean Region. Oxford University Press, Oxford. , 328p.

Bond, W.J. and Midgley, J.J., 2001. Ecology of sprouting in woody plants: the persistence niche. . Trends in Ecology and Evolution 16, 45-51.

Bradstock, R.A., Williams, J.E. and Gill, A.M., 2002. Flammable Australia. The Fire Regimes and Biodiversity of a Continent. Cambridge University Press.

Brewer, S., Cheddadi, R., De Beaulieu, J.L. and Reille, M., 2002. The spread of deciduous Quercus throughout Europe since the last glacial period 39. Forest Ecology and Management 156, $27-$ 48 .

Burjachs, F.G., S.; Roca, J.R.; Seret, G.; Juliá, R., , 1997. Palinología holocénica y desertización en el Mediterráneo occidental. In: J. J. V. Ibáñez, B.L.; Machado, C. (Ed.) El paisaje mediterráneo a través del espacio y del tiempo. Implicaciones en la desertificación, pp. 379394. Geoforma Editores, Logroño.

Butzer, K.W., 2005. Environmental history in the Mediterranean world: cross-disciplinary investigation of cause-and-effect for degradation and soil erosion. Journal of Archaeological Science 32, 1773-1800.

Buxó, R., 1997. Arqueología de las Plantas. Crítica, Barcelona.

Cámalich, M.D. and Martín, D., 1999. El territorio almeriense desde los inicios de la producción hasta fines de la antigüedad. Un modelo: la Depresión de Vera y Cuenca del Río Almanzora. Arqueología Monografías. Junta de Andalucía, Sevilla.

Carcaillet, C., Almquist, H., Asnong, H., Bradshaw, R.H.W., Carrión, J.S., Gaillard, M.J., Gajewski, K., Haas, J.N., Haberle, S.G., Hadorn, P., Müller, S.D., Richard, P.J.H., Richoz, I., Rösch, M., Sánchez Goñi, M.F., von Stedingk, H., Stevenson, A.C., Talon, B., Tardy, C., Tinner, W., Tryterud, E., Wick, L. and Willis, K.J., 2002. Holocene biomass burning and global dynamics of the carbon cycle. Chemosphere 49, 845-863.

Carrión, J.S., 2002. Patterns and processes of Late Quaternary environmental change in a montane region of southwestern Europe. Quaternary Science Reviews 21, 2047-2066.

Carrión, J.S. and Van Geel, B., 1999. Fine-resolution Upper Weichselian and Holocene palynological record from Navarrés (Valencia, Spain) and a discussion about factors of Mediterranean forest succession. Review of Palaeobotany and Palynology 106, 209-236.

Carrión, J.S., Andrade, A., Bennett, K.D., Navarro, C. and Munuera, M., 2001a. Crossing forest thresholds: inertia and collapse in a Holocene sequence from south-central Spain. The Holocene 11, 635-653.

Carrión, J.S., Munuera, M., Dupré, M. and Andrade, A., 2001b. Abrupt vegetation changes in the Segura Mountains of Southern Spain throughout the Holocene. Journal of Ecology 89, 783797. 
Carrión, J.S., Sánchez-Gomez, P., Mota, J.F., Y11, R. and Chain, C., 2003a. Holocene vegetation dynamics, fire and grazing in the Sierra de Gador, southern Spain. The Holocene 13, 839849.

Carrión, J.S., Y11, E.I., Walker, M.J., Legaz, A.J., Chaín, C. and López, A., 2003b. Glacial refugia of temperate, Mediterranean and Ibero-North African flora in south-eastern Spain: new evidence from cave pollen at two Neanderthal man sites. Global Ecology \& Biogeography 12, 119-129.

Carrión, J.S., Fuentes, N., González-Sampériz, P., Sánchez Quirante, L., Finlayson, J.C., Fernández, S. and Andrade, A., 2007. Holocene environmental change in a montane region of southern Europe with a long history of human settlement. Quaternary Science Reviews 26, 1455 1475.

Castro, P.V., Chapman, R.W., Suriñach, S., Lull, V., Micó, R., Rihuete, C., Risch, R. and Sanahuja, M.E., 1999. Proyecto Gatas. 2. La dinámica arqueoecológica de la ocupación prehistórica. . Junta de Andalucía, Sevilla.

Cheddadi, R., Yu, G., Guiot, J., Harrison, S.P. and Prentice, I.C., 1996. The climate of Europe 6000 years ago. Climate Dynamics 13, 1-9.

Colombaroli, D., Marchetto, A. and Tinner, W., 2007. Long-term interactions between Mediterranean climate, vegetation and fire regime at Lago di Massaciuccoli (Tuscany, Italy). Journal of Ecology 95, 755-770.

Colombaroli, D., Vanniere, B., Emmanuel, C., Magny, M. and Tinner, W., 2008. Fire--vegetation interactions during the Mesolithic--Neolithic transition at Lago dell'Accesa, Tuscany, Italy. The Holocene 18, 679-692.

Díaz-Andreu, M. and Keay, S.J., 1997. The archaeology of Iberia: the dynamics of change. Routledge, England.

Elmqvist, T., Folke, C., Nystrom, M., Peterson, G., Bengtsson, J., Walker, B. and Norberg, J., 2003. Response diversity, ecosystem change, and resilience. Frontiers in Ecology and the Environment 1, 488-494.

Finsinger, W. and Tinner, W., 2005. Minimum count sums for charcoal-concentration estimates in pollen slides: accuracy and potential errors. Holocene 15, 293-297.

Franco Múgica, F., García Antón, M., Maldonado Ruíz, J., Morla Juaristi, C. and Sainz Ollero, H., 2001. The Holocene history of Pinus forest in the Spanish Northern Meseta. 11,3, 343-358.

Franco Múgica, F., García Antón, M. and Sainz Ollero, H., 1998. Vegetation dynamics and human impact in the Sierra de Guadarrama, Central System, Spain. The Holocene 8, 69-82.

García Antón, M., Franco Múgica, F., Maldonado, J., Morla Juaristi, C. and Sainz Ollero, H., 1997. New data concerning the evolution of the vegetation in Lillo Pinewood (León, Spain). Journal of Biogeography 26, 929-934.

García Antón, M., Franco Múgica, F., Maldonado Ruiz, J., Morla Juaristi, C. and Sainz Ollero, H., 1995. Una secuencia polínica en Quintana Redonda (Soria). Evolución holocena del tapiz vegetal en el Sistema Ibérico septentrional. Anales del Jardín Botánico de Madrid 52, 187 195.

Gil García, M.J., Ruiz Zapata, M.B., Santisteban, J., Mediavilla, R., López-Pamo, E. and Dabrio, C., 2007. Late holocene environments in Las Tablas de Daimiel (south central Iberian peninsula, Spain). Vegetation History and Archaeobotany 16, 241-250.

Grimm, E., 1991. Tilia and Tiliagraph, version 2.0. and TG View version 1.6.2.

Jordán, J.F., 1992. Prospección arqueológica en la Comarca de Hellín—Tobarra. Metodolog!1a, resultados y bibliograf!1a. Al-Basit

$31,183-227$. 
Keeley, J.E., 1991. Seed germination and life history syndromes in the Californian Chaparral. Botanical Review 57, 81-116.

Lavorel, S., Canadell, J., Rambal, S. and Terradas, J., 1998. Mediterranean Terrestrial Ecosystems: Research Priorities on Global Change Effects. Global Ecology and Biogeography Letters 7, 157-166.

Martí, B., 1988. Early farming communities in Spain. Berytus 36, 69-86.

Martí, B., Pascual, V., Gallart, M.D., López, P., Pérez, M., Acuña, D. and Robles, F., 1980. Cova de l'Or (Beniarre's, Alicante). Servicio de Investigación de Prehistoria, Valencia.

McClure, S.B., Balaguer, L.M. and Auban, J.B., 2008. Neolithic rock art in context: Landscape history and the transition to agriculture in Mediterranean Spain. Journal of Anthropological Archaeology 27, 326-337.

Médail, F. and Quézel, P., 1999. Biodiversity Hotspots in the Mediterranean Basin: Setting Global Conservation Priorities. Conservation Biology 13, 1510-1513.

Morellón, M., Valero-Garcés, B., Moreno, A., González-Sampériz, P., Mata, P., Romero, O., Maestro, M. and Navas, A., 2008. Holocene palaeohydrology and climate variability in northeastern Spain: The sedimentary record of Lake Estanya (Pre-Pyrenean range). Quaternary International 181, 15-31.

Moritz, M. and Stephens, S., 2008. Fire and sustainability: considerations for California's altered future climate. Climatic Change 87, 265-271.

Nocete, F., 2001. Tercer Milenio antes de Nuestra Era. Relaciones y contradicciones centro/ periferia en el Valle del Guadalquivir. Bellaterra. Barcelona.

Pausas, J.G., 2004. Changes in fire and climate in the eastern Iberian Peninsula (Mediterranean basin). Climatic Change 63, 337-350.

Pausas, J.G. and Keeley, J.E., 2009. A Burning Story: The Role of Fire in the History of Life. BioScience 59, 593-601.

Pausas, J.G., Bradstock, R.A., Keith, D.A., Keeley, J.E. and Network, G.F., 2004. Plant functional traits in relation to fire in crown-fire ecosystems. Ecology 85, 1085-1100.

Pausas, J., Llovet, J., Rodrigo, A. and Vallejo, R., 2008 Are wildfires a disaster in the Mediterranean basin? - A review. International Journal of Wildland Fire 17, 713-723.

Petit, R.J., Brewer, S., Bordács, S., Burg, K., Cheddadi, R., Coart, E., Cottrell, J., Csaikl, U.M., van Dam, B., Deans, J.D., Espinel, S., Fineschi, S., Finkeldey, R., Glaz, I., Goicoechea, P.G., Jensen, J.S., König, A.O., Lowe, A.J., Madsen, S.F., Mátyás, G., Munro, R.C., Popescu, F., Slade, D., Tabbener, H., de Vries, S.G.M., Ziegenhagen, B., de Beaulieu, J.-L. and Kremer, A., 2002. Identification of refugia and post-glacial colonisation routes of European white oaks based on chloroplast DNA and fossil pollen evidence. Forest Ecology and Management $156,49-74$.

Prentice, I.C. and Webb, T., 1998. BIOME 6000: reconstructing global mid-Holocene vegetation patterns from palaeoecological records 21. Journal of Biogeography 25, 997-1005.

Puigdefábregas, J. and Mendizábal, T., 1998. Perspectives on desertification: western Mediterranean. Journal of Arid Environments 39, 209-224.

Rodríguez-Ariza, M. and Moya, E., 2005. On the origin and domestication of Olea europaea L. (olive) in Andalucía, Spain, based on the biogeographical distribution of its finds. Vegetation History and Archaeobotany 14, 551-561.

Rodríguez-Ariza, M.O. and Ruiz-Sánchez, V., 1993. Acción antrópica sobre el medio natural en el sureste de Andalucía durante la Prehistoria reciente y época romana Investigaciones arqueológicas en Andalucía 1985-1992., pp. 417-428. Consejería de Cultura y Medio Ambiente de la Junta de Andalucía, Huelva. 
Sadori, L. and Giardini, M., 2007. Charcoal analysis, a method to study vegetation and climate of the Holocene: The case of Lago di Pergusa (Sicily, Italy). Geobios 40, 173-180.

Sadori, L., Zanchetta, G. and Giardini, M., 2008. Last Glacial to Holocene palaeoenvironmental evolution at Lago di Pergusa (Sicily, Southern Italy) as inferred by pollen, microcharcoal, and stable isotopes. Quaternary International 181, 4-14.

Sánchez-Quirante, L., 1998. Historia. In: J. A. Rodríguez-Sánchez (Ed.) Guía para conocer y visitar el Parque Natural de la Sierra de Baza. 141-148. Asociación Proyecto Sierra de Baza, Baza, Granada.

Stuiver, M., Reimer, P.J., Bard, E., Beck, J.W., Burr, G.S., Hughen, K.A., Kromer, B., McCormac, G., van der Plicht, J. and Spurk, M., 1998. INTCAL98 radiocarbon age calibration, 24,000-0 cal BP. Radiocarbon 40, 1041-1083.

Tapias, R., Gil, L., Fuentes-Utrilla, P. and Pardos, J.A., 2001. Canopy seed bank in Mediterranean pines of south-eastern Spain: a comparison between Pinus halepensis Mill, P. pinaster Ait., P. nigra Arn. and P. pinea L. . Journal of Ecology 89, 629-638.

Tinner, W. and Sheng Hu, F., 2003. Size parameters, size-class distribution and area-number relationship of microscopic charcoal:relevance for fire reconstruction. The Holocene 13, 499-505.

Tinner, W., van Leeuwen, J.F.N., Colombaroli, D., Vescovi, E., van der Knaap, W.O., Henne, P.D., Pasta, S., D'Angelo, S. and La Mantia, T., 2009. Holocene environmental and climatic changes at Gorgo Basso, a coastal lake in southern Sicily, Italy. Quaternary Science Reviews $28,1498-1510$.

Turner, R., Roberts, N. and Jones, M.D., 2008. Climatic pacing of Mediterranean fire histories from lake sedimentary microcharcoal Global and Planetary Change, 63, 317-324.

Vannière, B., Colombaroli, D., Chapron, E., Leroux, A., Tinner, W. and Magny, M., 2008. Climate versus human-driven fire regimes in Mediterranean landscapes: the Holocene record of Lago dell'Accesa (Tuscany, Italy). Quaternary Science Reviews 27, 1181-1196.

Vázquez, A., García del Barrio, J.M., Ortega Quero, M. and Sánchez Palomares, O., 2006. Recent fire regime in peninsular Spain in relation to forest potential productivity and population density. International Journal of Wildland Fire 15, 397-405.

Whitlock, C., Bianchi, M.M., Bartlein, P.J., Markgraf, V., Marlon, J., Walsh, M. and McCoy, N., 2006. Postglacial vegetation, climate, and fire history along the east side of the Andes (lat 41-42.5 degrees S), Argentina 2. Quaternary Research 66, 187-201.

Wick, L., Lemcke, G. and Sturm, M., 2003. Evidence of Lateglacial and Holocene climatic change and human impact in eastern Anatolia: high-resolution pollen, charcoal, isotopic and geochemical records from the laminated sediments of Lake Van, Turkey. The Holocene 13, 665-675.

\section{Figure and table captions}

Figure 1. Location map for the studied locations (white diamonds) and the archaeological sites (white squares): 1, Cova de l'Or; 2, Cueva del Nacimiento; 3, Terrera Ventura; 4, Los Millares; 5, Les Jovades; 6, Carihuela; 7, Cerro de la Virgen; 8, Cova Ampla; 9, Cova de la Recambra; 10, Cueva del Toro; 11, Les Cendres; 12, Nerja; 13, San Benito. Further details for the study and archaeological sites are shown in Table 1 and 2 respectively.

Figure 2. NCHAR (A and C) and millennial averaged FAA (B and D) for the sites studied in this paper. NCHAR and FAA have no units. (See details in text). 
Figure 3a: Synthetic pollen percentage diagrams for Baza, Cañada and Siles, with the NCHAR and millennial averaged FAA sequences shown on top. The taxa are grouped according to plant functional types in Table 3.

Figure 3b: Synthetic pollen diagrams for Gádor, Villaverde and Navarrés, with the NCHAR and millennial averaged FAA sequences shown on top. The taxa are grouped according to plant functional types in Table 3.

Figure 4: Fire anomalies based on NCHAR differences between the target periods and 3 kyr cal BP. This difference is qualitatively represented in every map period as strongly negative (large dark dots), negative (small dark dots), no change (inverted triangles) or positive (empty dots). Archaeological sites are represented as empty squares in every map (see details in text and table 2).

Table 1. Physical settings of the six sites analysed including the time span recorded in every chronology. MAT: Mean annual temperature $\left({ }^{\circ} \mathrm{C}\right)$. MAP: Mean annual precipitation (mm). Ref: original references where more information about vegetation history can be found: 1. Carrión et al. (2007), 2. Carrión et al. (2001a) 3. Carrión et al., (2003a), 4. Carrión, (2002), 5 Carrión et al. (2001b), 6. Carrión and Van Geel, (1999).

Table 2. Number, names and age of the archaeological sites in Figs. 1 and 4. Meso- refers to Mesolithic.

Table 3. Plant type, life form and regeneration strategy after crown-fire of the taxa discussed in this paper. 


\begin{tabular}{|c|c|c|c|c|c|c|c|c|c|c|}
\hline Locality & Type & Lat. & Long. & $\begin{array}{l}\text { Alt. } \\
\text { (masl) }\end{array}$ & Modern vegetation & Climate & MAT & MAP & Time span (cal yrs BP) & Ref \\
\hline Baza & Peat deposit & $37^{\circ} 14^{\prime}$ & $2^{\circ} 42^{\prime}$ & 1900 & $\begin{array}{l}\text { Mosaic of pine, oak and mixed pine-oak } \\
\text { woodlands }\end{array}$ & $\begin{array}{l}\text { Oromediterranean, cold } \\
\text { continental }\end{array}$ & $4-8$ & $500-600$ & $160-8390$ & 1 \\
\hline Cañada de la Cruz & $\begin{array}{l}\text { Shallow } \\
\text { lacustrine } \\
\text { deposit }\end{array}$ & $38^{\circ} 04^{\prime}$ & $2 \div 42^{\prime}$ & 1595 & $\begin{array}{l}\text { Dwarf junipers (Juniperus sabina and } J . \\
\text { communis), some Pinus nigra stands } \\
\text { and a thorny prostrate scrub }\end{array}$ & $\begin{array}{l}\text { Oro/Supra- } \\
\text { mediterranean, cold } \\
\text { continental }\end{array}$ & $5-8$ & $700-800$ & 1955AD-9350 & 2 \\
\hline Gádor & $\begin{array}{l}\text { Shallow } \\
\text { lacustrine } \\
\text { deposit }\end{array}$ & $36^{\circ} 52^{\prime}$ & $2^{\circ} 55^{\prime}$ & 1530 & $\begin{array}{l}\text { Sparse presence of trees: Pinus, } \\
\text { Quercus with a continental understorey }\end{array}$ & $\begin{array}{l}\text { Supramediterranean, } \\
\text { cold continental }\end{array}$ & $11-12$ & $450-500$ & $1160-6850$ & 3 \\
\hline Siles & Lake & $38^{\circ} 24^{\prime}$ & $2^{\circ} 30^{\prime}$ & 1320 & $\begin{array}{l}\text { Patches of Pinus nigra, P. pinaster and } \\
\text { evergreen Quercus. Juniperus is } \\
\text { relatively frequent }\end{array}$ & $\begin{array}{l}\text { Mesomediterranean, } \\
\text { cold subhumid }\end{array}$ & $10-11$ & $800-1000$ & $504-9840$ & 4 \\
\hline Villaverde & Tufaceous peat & $38^{\circ} 47^{\prime}$ & $2^{\circ} 22^{\prime}$ & 870 & $\begin{array}{l}\text { Patches of evergreen Quercus, scattered } \\
\text { Juniperus and Pinus (P.Pinaster and } P \text {. } \\
\text { nigra) woodlands in the adjacent } \\
\text { mountains }\end{array}$ & $\begin{array}{l}\text { Mesomediterranean, } \\
\text { dry continental }\end{array}$ & $13-14$ & $400-450$ & $1160-9730$ & 5 \\
\hline Navarrés & $\begin{array}{l}\text { Peat overlying a } \\
\text { lacustrine } \\
\text { deposit }\end{array}$ & $39^{\circ} 7^{\prime}$ & $0^{\circ} 41^{\prime}$ & 225 & $\begin{array}{l}\text { Garrigue and cultures with patches of } \\
\text { evergreen Quercus }\end{array}$ & Thermomediterranean & $15-16$ & $500-550$ & $3378-10186$ & 6 \\
\hline
\end{tabular}

Table 1 


\begin{tabular}{lll} 
number & \multicolumn{1}{c}{ archaeological site } & \multicolumn{1}{c}{ age } \\
1 & Cova de l'Or & Neolithic \\
2 & Cueva del Nacimiento & Neo-Calcolithic \\
3 & Terrera Ventura & Calcolithic \\
4 & Los Millares & Calcolithic \\
5 & Les Jovades & Calcolithic \\
6 & Carihuela & Neolithic \\
7 & Cerro de la Virgen & Calcolithic \\
8 & Cova Ampla & Neolithic \\
9 & Cova de la Recambra & Calcolithic \\
10 & Cueva del Toro & Neolithic \\
11 & Les Cendres & Meso-Neolithic \\
12 & Nerja & Neolithic \\
13 & San Benito & Neolithic \\
& & \\
& Mesolithic & 12-7.4 cal Kyr BP \\
& Neolíthic & $7.4-5.7$ cal Kyr BP \\
& Calcolithic & $5.7-4.5$ cal Kyr BP
\end{tabular}

Table 2 


\begin{tabular}{|c|c|c|c|c|}
\hline Acronym & Plant type & Taxa included & $\begin{array}{c}\text { Life form } \\
\text { (or functional type) }\end{array}$ & $\begin{array}{l}\text { Post-fire response } \\
\text { strategy }\end{array}$ \\
\hline MES & Mesophytes & $\begin{array}{l}\text { Fraxinus, Salix, Acer, } \\
\text { Castanea, Corylus, Betula, } \\
\text { Alnus }\end{array}$ & Broadleaf deciduous trees & Obligate resprouters \\
\hline Querdec & Deciduous Quercus & Quercus faginea, & Broadleaf deciduous trees & Obligate resprouters \\
\hline MED & Mediterranean & $\begin{array}{l}\text { Pistacia, Phyllirea, Olea, } \\
\text { Rhamnus }\end{array}$ & $\begin{array}{l}\text { Broadleaf evergreen trees } \\
\text { and shrubs }\end{array}$ & Obligate resprouters \\
\hline Querever & \multicolumn{2}{|c|}{ Evergreen Quercus } & $\begin{array}{l}\text { Broadleaf evergreen } \\
\text { trees/shrubs }\end{array}$ & Obligate resprouters \\
\hline Quersub & \multicolumn{2}{|c|}{ Quercus suber } & $\begin{array}{l}\text { Broadleaf evergreen } \\
\text { trees/shrubs }\end{array}$ & Obligate resprouters \\
\hline Pinpin & \multicolumn{2}{|c|}{ Pin us pinaster, P.halepensis } & \multicolumn{2}{|c|}{ Needleleaf evergreen trees Obligate seeder } \\
\hline Pinnig & \multicolumn{2}{|c|}{ Pinus nigra, $P$. sylvestris } & Need leleaf evergreen trees & Without any strategy \\
\hline ANTHR & Anthropic elements & $\begin{array}{l}\text { Juglans, Plantago, Cerealia, } \\
\text { Centaurea, Papaver }\end{array}$ & Variable & Variable \\
\hline XER & Xerophytes & $\begin{array}{l}\text { Artemisia , Asteraceae, } \\
\text { Chenopodiaceae, Ephedra, } \\
\text { Lamiaceae }\end{array}$ & $\begin{array}{l}\text { Variable (mainly shrubs } \\
\text { and scrubs) }\end{array}$ & Variable \\
\hline
\end{tabular}

Table 3 


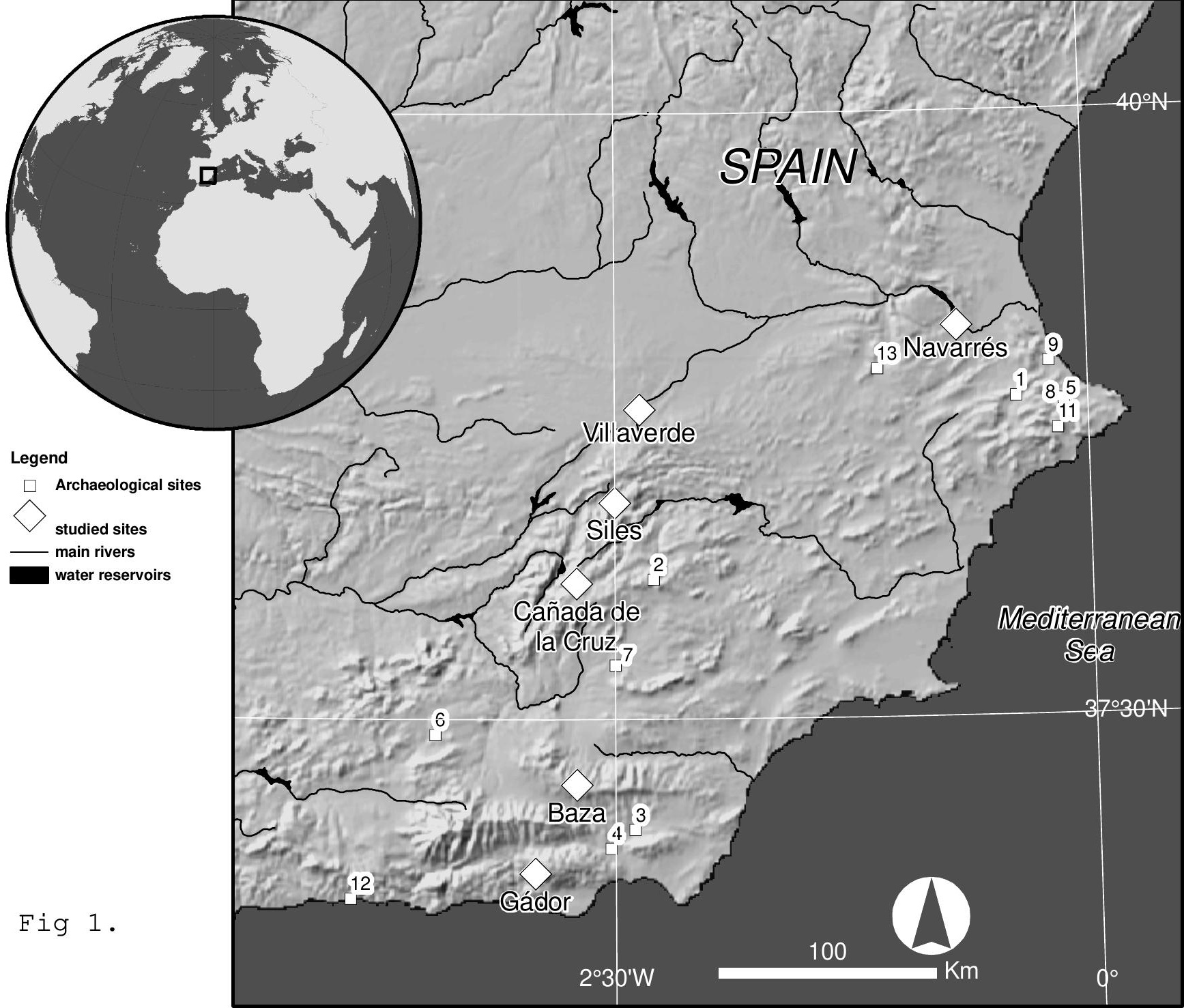


Baza

A

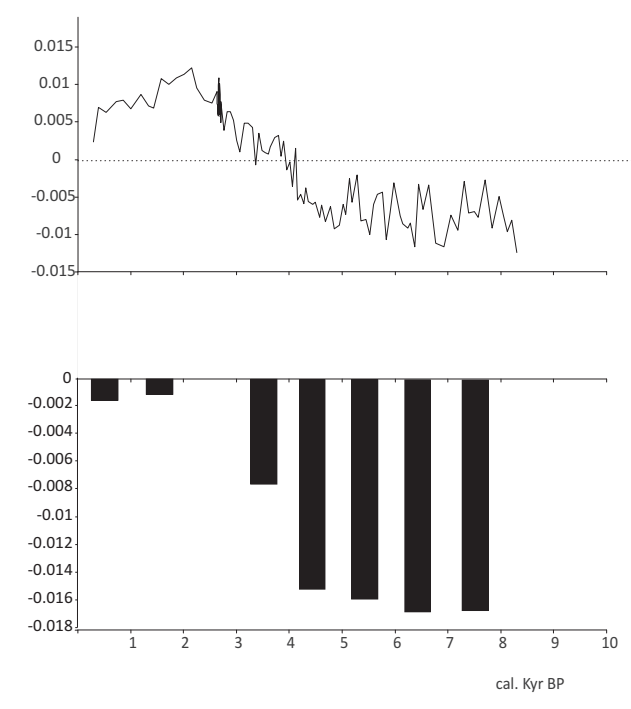

Villaverde

C

D

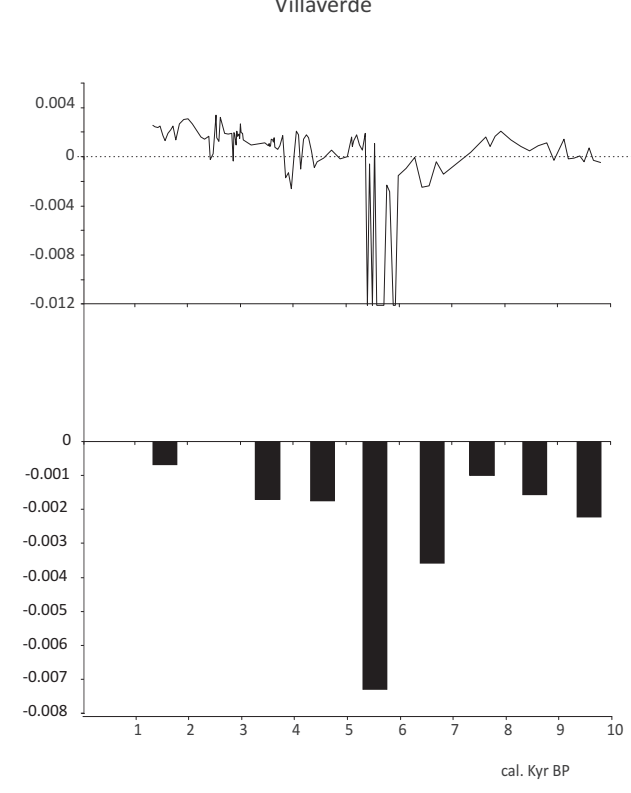

Gádor

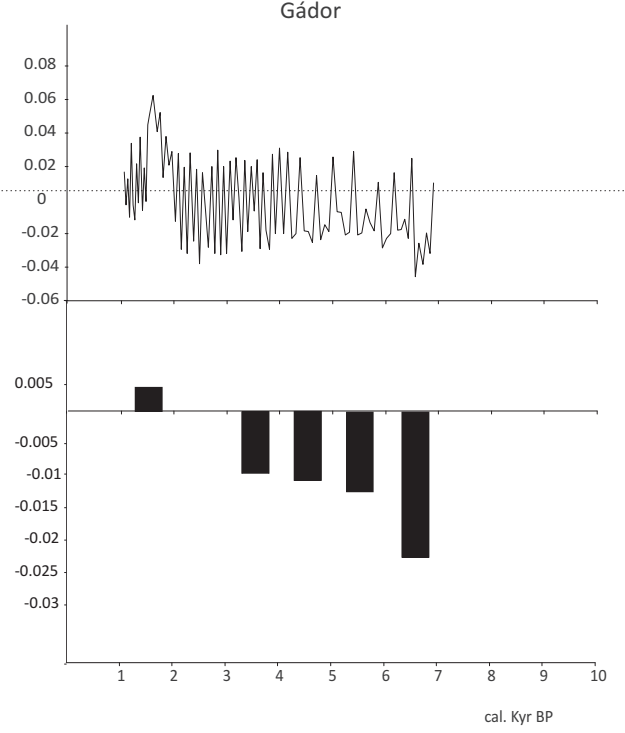

Siles

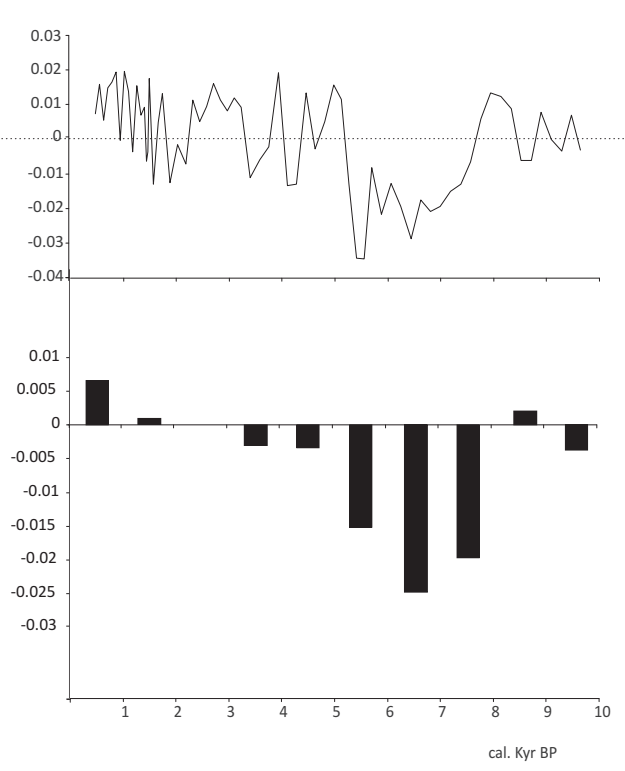

Cañada

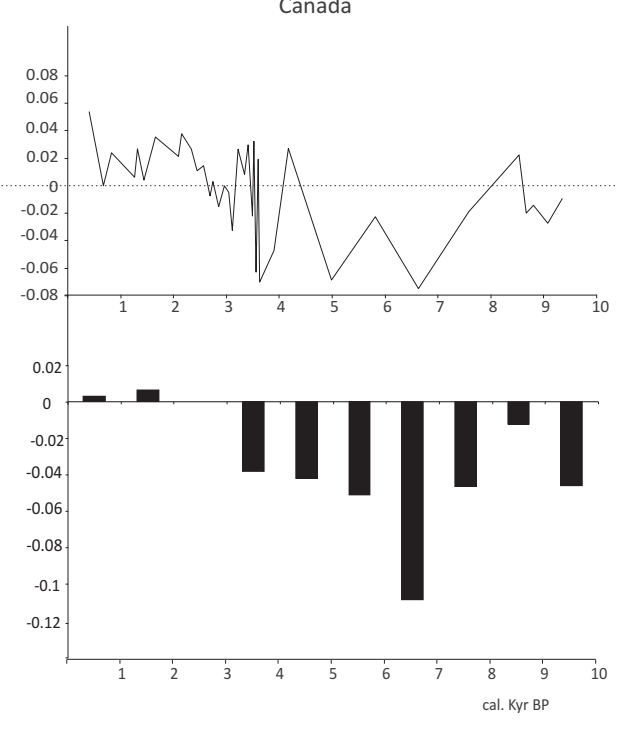

Navarrés

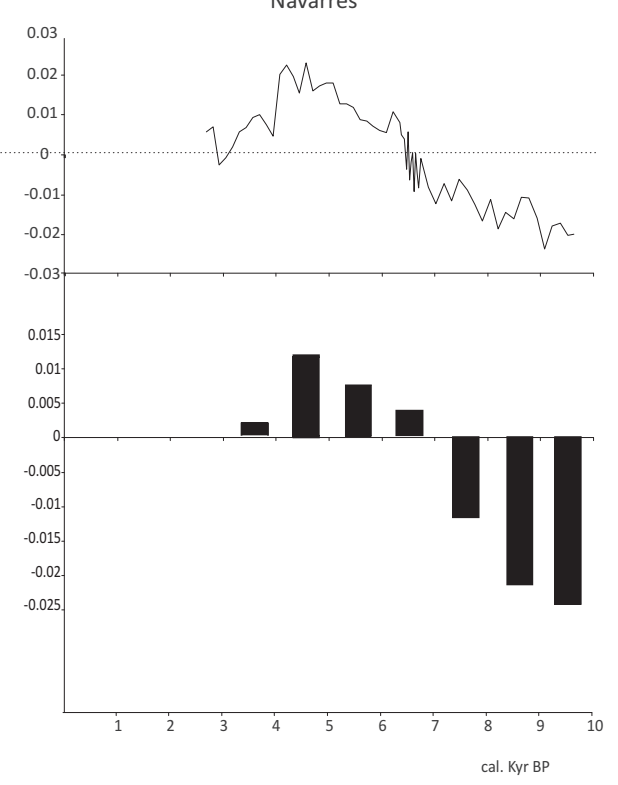

Fig. 2 

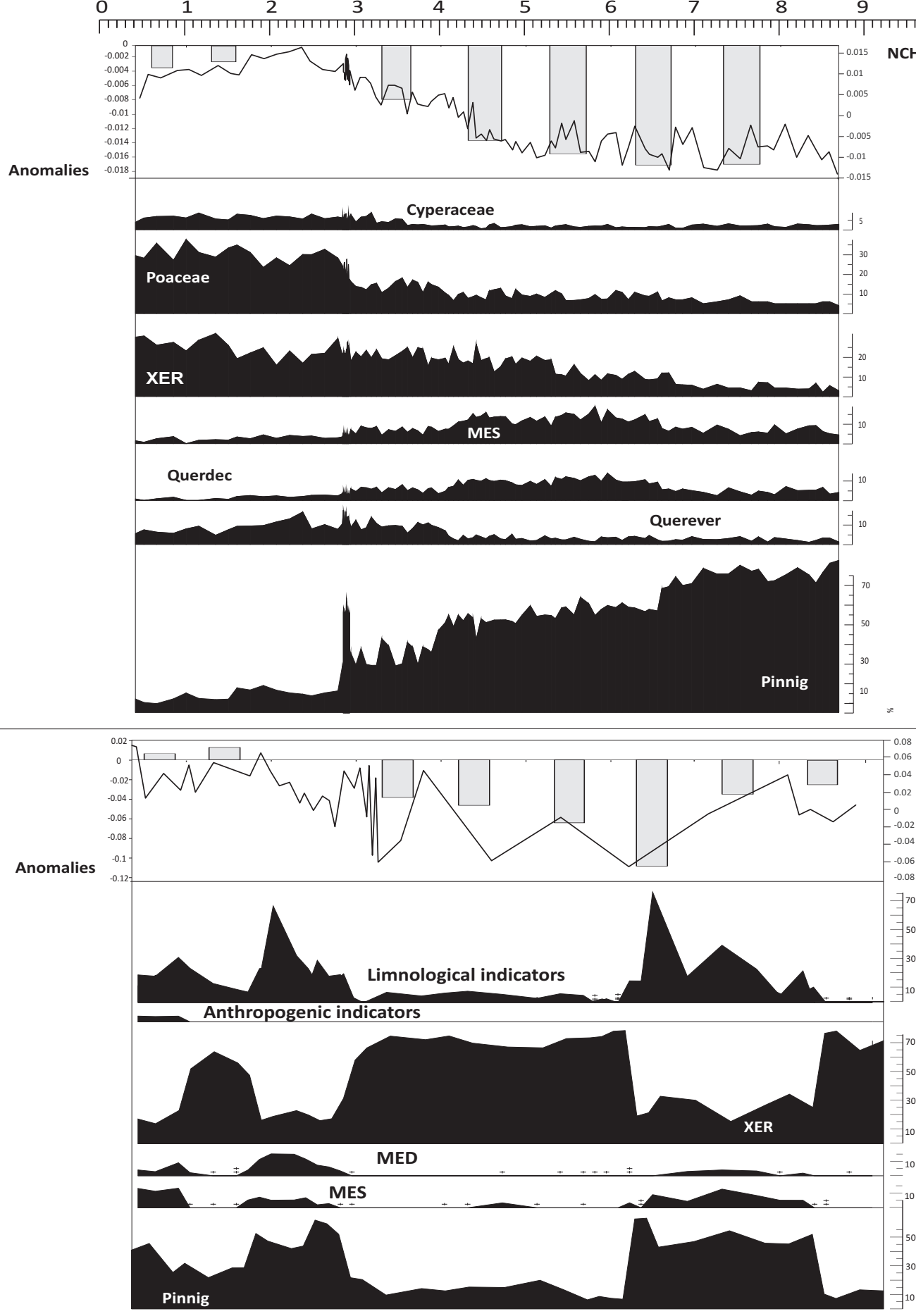

Cañada

(1595 masl)

Fig. $3 a$

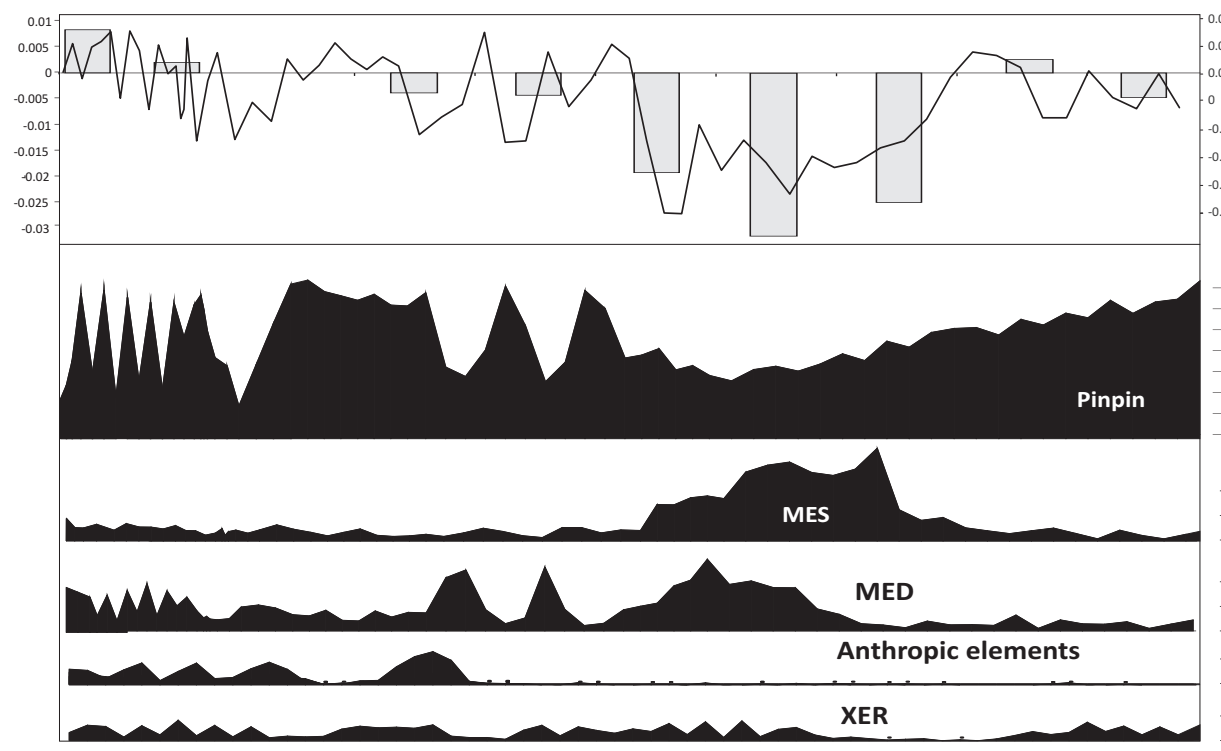

NCHAR

Siles

(1320 masl) 

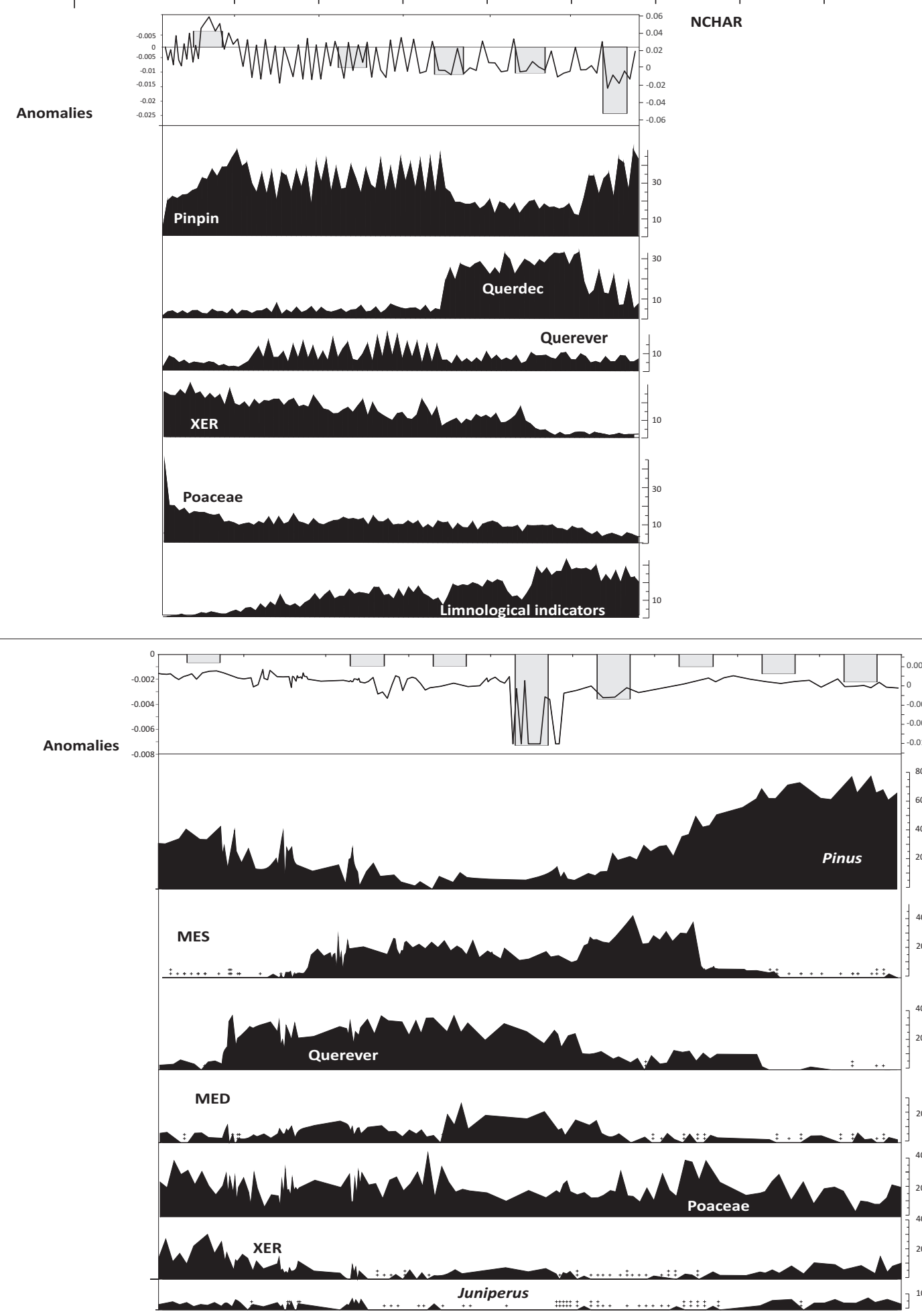

Fig. 3b

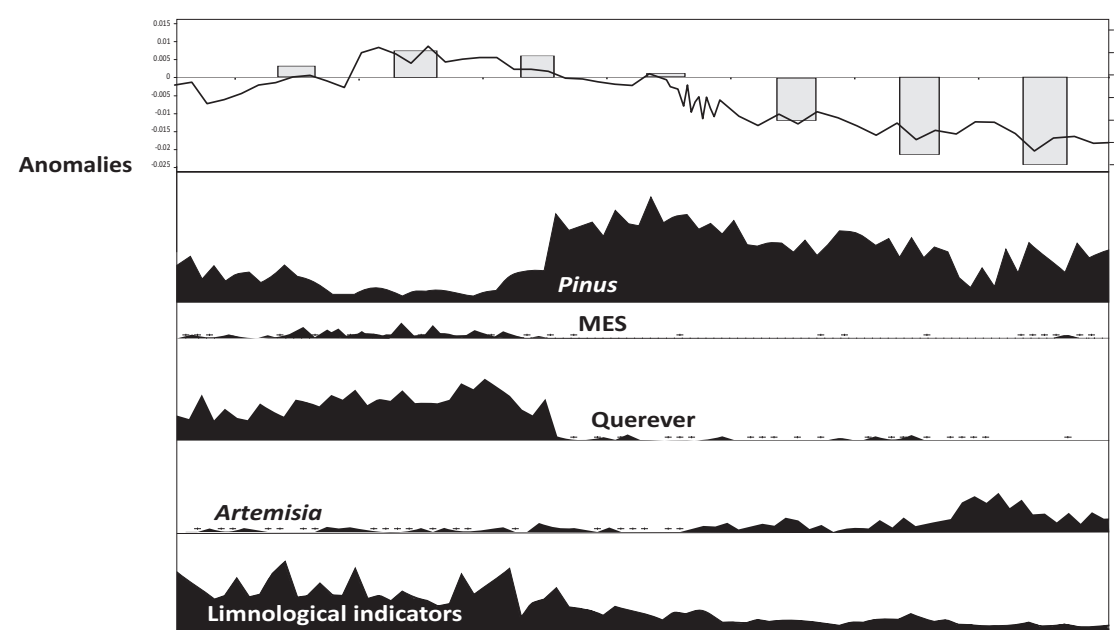

NCHAR

Navarrés

(225 masl) 

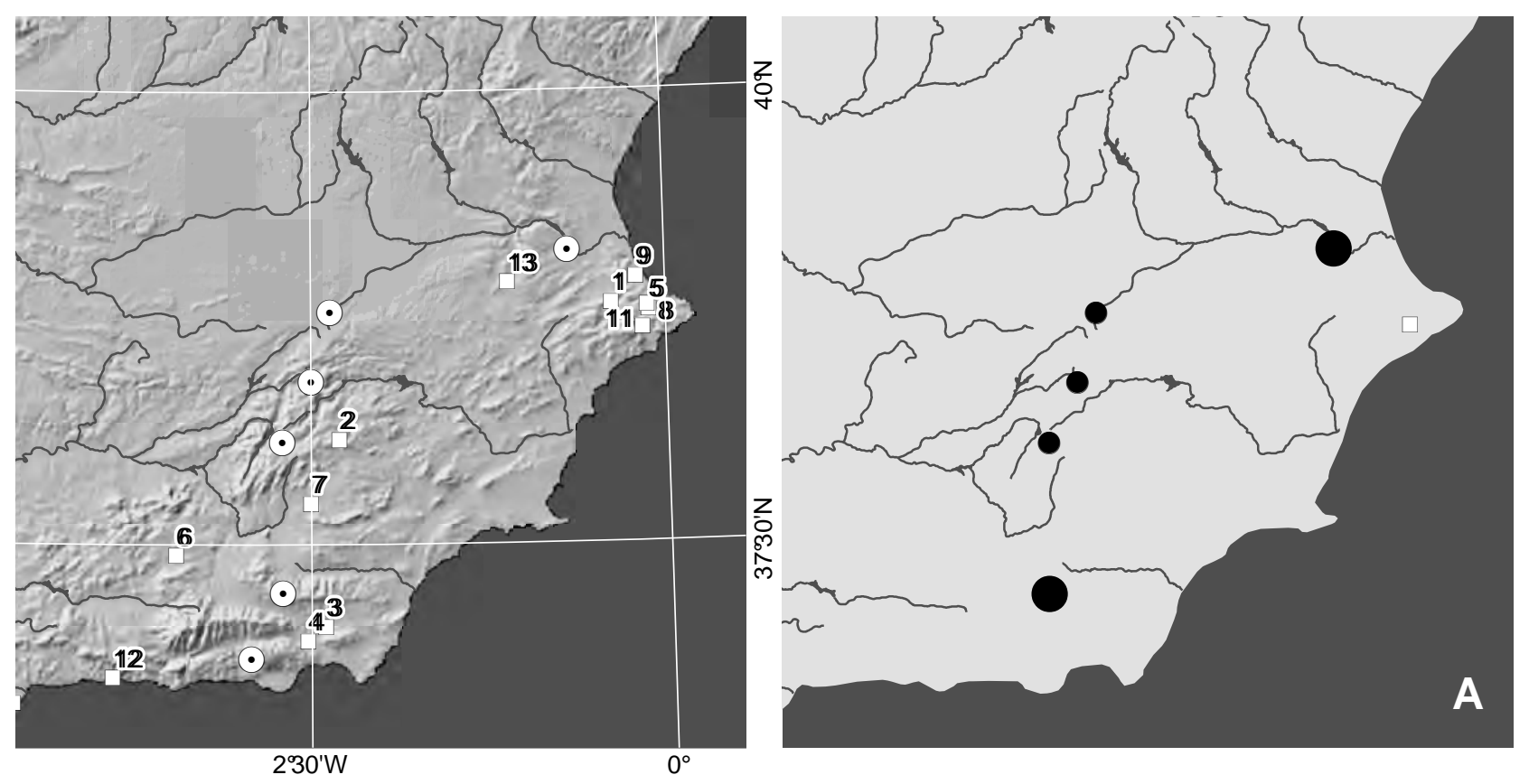

\section{Legend}

$\square$ archeological sites

$\odot$ studied sites

main rivers

water reservoirs
Anomalies

Positive

$\nabla$ No change

- Negative

Strongly negative
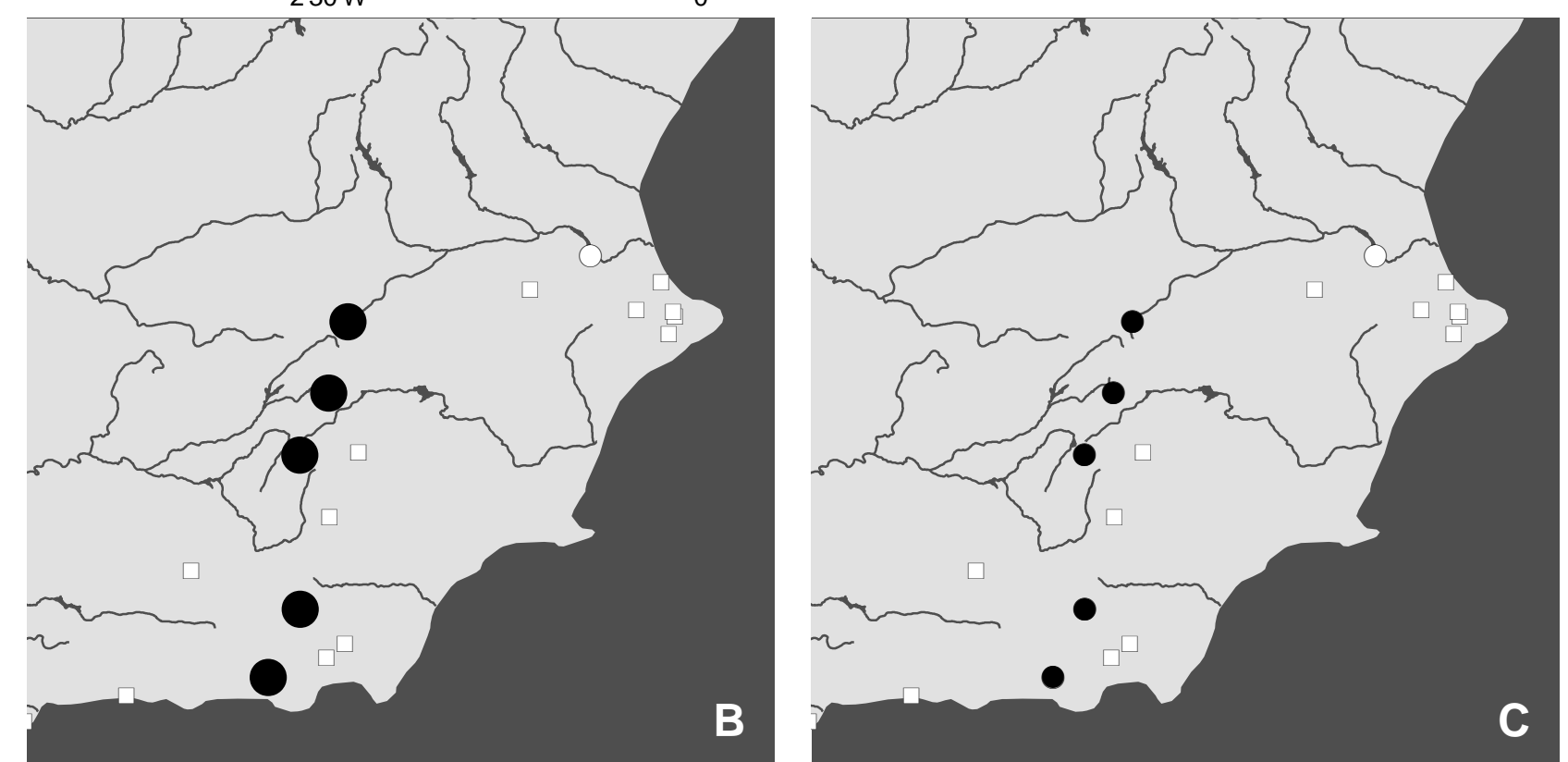

A: Early Holocene: 10-8 cal Kyr BP

B: Mid-Holocene: 6 cal Kyr BP

C: Late Holocene: 4 cal Kyr BP

D: Present: last 500 years

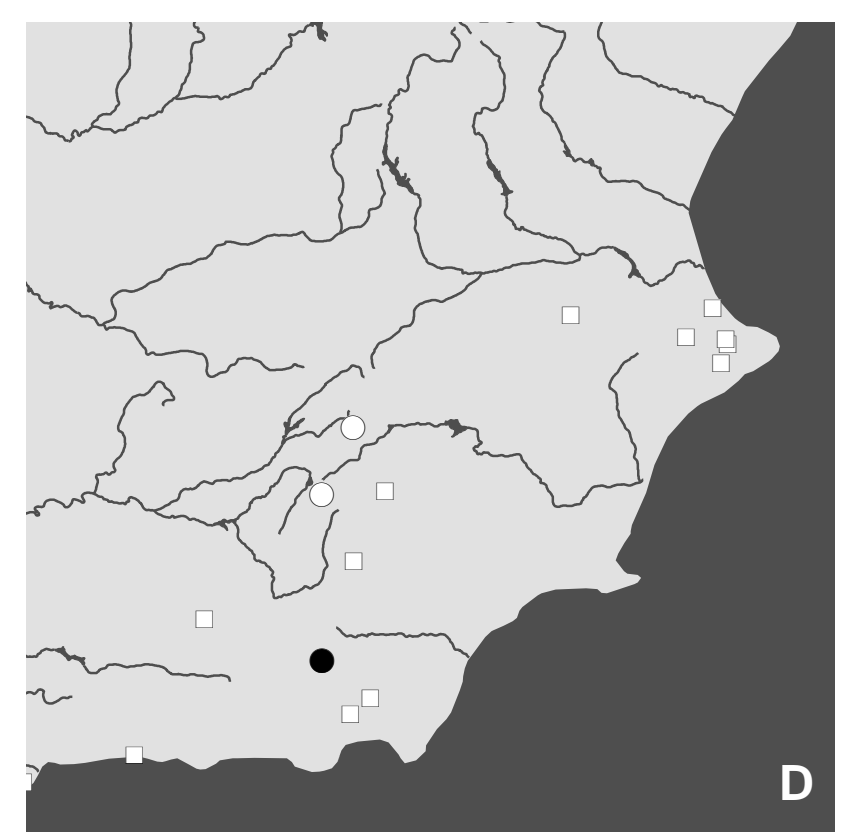

